\title{
GBA wt Allele
}

National Cancer Institute

\section{Source}

National Cancer Institute. GBA wt Allele. NCI Thesaurus. Code C104422.

Human GBA wild-type allele is located in the vicinity of $1 \mathrm{q} 22$ and is approximately $10 \mathrm{~kb}$ in length. This allele, which encodes glucosylceramidase protein, plays a role in glycolipid metabolism. Mutations in this gene are associated with Gaucher disease. 